\title{
On rising temperature trends at Dehradun in Doon valley of Uttarakhand, India
}

\author{
Omvir Singh ${ }^{1, *}$, Poonam Arya ${ }^{1}$ and Bhagwan Singh Chaudhary ${ }^{2}$ \\ ${ }^{1}$ Department of Geography, Kurukshetra University, Kurukshetra 136 119, India. \\ ${ }^{2}$ Department of Geophysics, Kurukshetra University, Kurukshetra 136 119, India. \\ *Corresponding author.e-mail: ovshome@yahoo.com ovshome@gmail.com
}

Climate change is one of the most important issues among researchers, scientists, planners and politicians in the present times. Of all the climatic elements, temperature plays a major role in detecting climatic change brought about by urbanization and industrialization. This paper, therefore, attempts to study the temperature changes at Dehradun city by analyzing the time series data of annual maximum, minimum and mean temperature from 1967 to 2007 . Data for the study has been analyzed in three parts by running linear regression and by taking anomalies for the whole period from 1967 to 2007, phase one 1967-1987 and phase two 1988-2007. The study of linear trend indicated increasing trends in annual maximum, annual minimum and annual mean temperatures. During 1967-2007 annual maximum, annual minimum and annual mean temperatures increased about $0.43^{\circ} \mathrm{C}, 0.38^{\circ} \mathrm{C}$ and $0.49^{\circ} \mathrm{C}$, respectively. The analysis of temperature data in two phases also revealed an increase in annual maximum, annual minimum and annual mean temperature. However, temperature increase in second phase was more pronounced in relation to first phase. During second phase (1988-2007) annual maximum, annual minimum and annual mean temperatures increased about $0.42^{\circ} \mathrm{C}, 0.59^{\circ} \mathrm{C}$ and $0.54^{\circ} \mathrm{C}$, respectively. The perceptible increase in temperature during second phase is mainly attributed to urbanization and industrialization process initiated at Dehradun particularly after becoming the state capital of newly carved out state of Uttarakhand since the year 2000. The analysis also highlight significantly the role of extreme vulnerability of rising temperatures at Dehradun and urban population will constantly be affected by the change in the temperature which controls the comfort level of the inhabitants. Also, the rising temperatures in Doon valley are not a healthy signature for crop production and water resources in the region.

\section{Introduction}

Artificially induced climate change and global warming arising from anthropogenic-driven emissions of greenhouse gases and land-use and landcover change have emerged as one of the most important environmental issues among researchers in the last two decades (Kadioğlu 1997; Arora et al. 2005; Singh et al. 2008). The emission of greenhouse gases has increased considerably since the industrial revolution (1750 onwards), with an increase of $70 \%$ between 1970 and 2004 (Singh et al. 2008; Revadekar et al. 2012). The latest fourth assessment report of the Intergovernmental Panel on Climate Change (IPCC 2007) has concluded that the global mean surface temperatures have risen by $0.74 \pm 0.18^{\circ} \mathrm{C}$ when estimated by a linear trend over the last 100 years (1906-2005). The rate of warming over the recent 50 years is almost double of that over the last 100 years (IPCC

Keywords. Climate change; greenhouse gases; temperature trend; global warming; Doon valley. 
2007), which is largely attributed to anthropogenic influences. Weather records from land stations and ships indicate that the global mean surface temperature has warmed up approximately by $0.6 \pm$ $0.2^{\circ} \mathrm{C}$ since 1850 and it is expected that, by 2100 , the increase in temperature could be $1.4^{\circ}-5.8^{\circ} \mathrm{C}$ (Singh et al. 2008). Moreover, the world has witnessed change in climatic condition at an unprecedented rate in past few decades. Available records show that the 1990s have been the warmest decade of the millennium in the Northern Hemisphere and 1998 was the warmest year.

Today, the world population is approximately 7 billion and grows by nearly 80 million people each year (Sajjad et al. 2009). The dramatic acceleration of urban growth is a universal phenomenon in most countries of the world ( $\mathrm{Xu}$ et al. 2010). Approximately half of the world population currently lives in cities, and this value is expected to increase to $61 \%$ by 2030 (UNFPA 2009). Moreover, about $80 \%$ of future economic growth will occur in cities (Gupta 2004). No doubt, the urbanization (residential, commercial and industrial development) is playing and will continue to play an important role in shaping a country's economy but, they are also burdened with many problems associated with growth and the physical environment (Roth 2007; Rana et al. 2012). Urbanization transforms natural landscape to artificial landscape, and therefore alters radiative, thermal, roughness and moisture properties of the surface and the atmosphere above (Hung et al. 2006). Some of the urban locations are becoming increasingly vulnerable to natural hazards related to weather and climate (De and Dandekar 2001). Therefore, the study of urban climate is attracting significant attention in the present world (Catherine and Sue 2006). The studies have found differential rate of change in temperature over urban and rural areas and indicate that the warming tendency is more pronounced in urban areas than the surrounding rural areas (Tayanc and Toros 1997; Chung et al. 2004a; Trusilova et al. 2008). Fujibe (2009) demonstrated that urban warming was not only detectable at large cities but at slightly urbanized sites in Japan. All over the world urban areas are being affected by urban climate change. Increasing temperatures of Dhaka (Alam and Golam Rabbani 2007), increase of $2^{\circ} \mathrm{C}$ temperature of Sao Paolo since 1993 (Edmilson et al. 2007), increasing tendencies of Beijing temperatures from 1977-2000 (Liu et al. 2007) and $1.5^{\circ} \mathrm{C}$ increase in annual mean temperature of Seoul during last 29 years (Chung et al. 2004a) are the global examples of urban climate change.

Assessing the impacts of urbanization and land use change on mean surface temperature is a challenging task. Several studies have attempted to assess the effect of urbanization and industrialization on temperature trends (Chung et al. 2004b; De and Prakasa Rao 2004; Gadgil and Dhorde 2005; Kumar et al. 2005; Dash and Hunt 2007; Dhorde et al. 2009; Sajjad et al. 2009; Tigga and Hema Malini 2011). However, some studies have tried to establish a link between some of the intense man-made activities of urban industrial areas and temperature trends and found increased size and density of population, land use/land cover changes, reduction in the fraction of vegetative area exclusive use of fossil fuel combination and emission of waste heat from industries, automobiles and building construction activities (roads, buildings, reservoirs, etc.), excessive use of air conditioning, changing level of aerosols, etc., responsible for such urban-rural contrast in temperature trends (Thapliyal and Kulshreshtha 1991; Goodridge 1992; Fujibe 1995; Bounoua et al. 2004; Ohashi et al. 2007; Oleson et al. 2008; Yilmaz et al. 2009). In view of the importance of air temperature, as indicated in the preceding discussion, it would be of interest to study the long-term variation of surface air temperature at Dehradun in Uttarakhand, which, during the last two decades noticed phenomenal rise in urbanization and industrialization.

\section{Study area and its environmental problems}

Dehradun, belonging to Uttarakhand state of India, is located in a valley at the foothills of Himalayas and lies between $30^{\circ} 15^{\prime}$ and $30^{\circ} 25^{\prime}$ north latitudes and $78^{\circ} 00^{\prime}$ and $78^{\circ} 10^{\prime}$ east longitudes (figure 1). It is surrounded by river Song on the east, river Tons on the west, Himalayan ranges on the north and Sal forests in the south. The high hills in the east and north and Siwaliks in the south offer an interesting topographical setting to the city. During the summer months, the temperature ranges between $36^{\circ} \mathrm{C}$ and $16.7^{\circ} \mathrm{C}$. The winter months are colder with the maximum and minimum temperatures touching $23.4^{\circ} \mathrm{C}$ and $5.2^{\circ} \mathrm{C}$, respectively. Dehradun experiences heavy to moderate showers during late June to mid August. Most of the annual rainfall (about $2000 \mathrm{~mm}$ ) is received during the months from June to September, July and August being the rainiest months of the season.

The Dehradun city has emerged as an important business, educational and cultural destination in north India after becoming the capital of newly carved out Uttarakhand state since the year 2000. Moreover, city is the wholesale trading center for the entire hill region of the Uttarakhand state. The city is also well known for its salubrious climate, natural beauty, places for tourist's attraction and institutions of national and international 


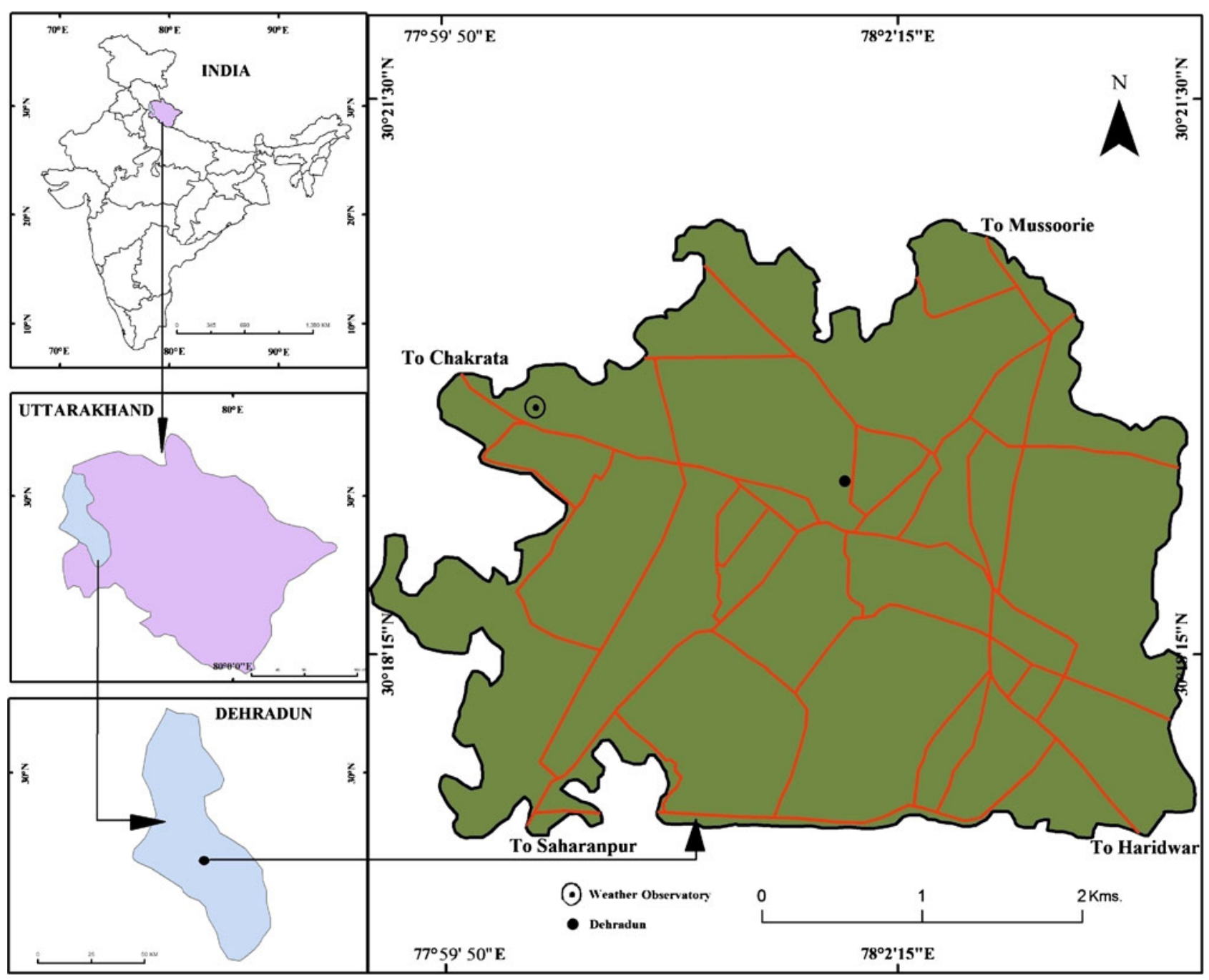

Figure 1. Extent of Dehradun city and location of meteorological station considered in this study.

importance. Therefore, about one million Indian and foreign tourists visit the city every year in the form of floating population (UUDP 2007). The resident population of the city grew alarmingly during 1991-2011 and it registered a growth of about $114 \%$ during the last two decades (figure 2). In addition, the population of the Dehradun city will grow at the rate of $3.5 \%$ from 2010 to 2014 , and $3.0 \%$ from 2015 to 2019 (UUDP 2007).

Several industries namely, pharmaceutical and chemicals, electronic and electrical engineering, food processing and glassware were established in Dehradun city after the declaration of state industrial development policy in the year 2003. This growth of population and industrialization was accompanied by alarming growth in built up area of Dehradun city (table 1). Commercial built up area in the city registered a growth of about $322 \%$ during 1982-2004. The major conversion into built up area in the city took place from agricultural land, forest areas and open spaces.
Alarming increase in vehicular traffic has been observed in the city after the initiation of growth in population, urbanization and industrialization process. A growth of about $362 \%$ was registered in the registration of vehicles in the last decade (UUDP 2007). Significant rise is also noticed in the number of vehicles that registered elsewhere but plying on the roads of Dehradun city and are emitting huge amount of heavier molecules, hydrocarbons, NOx, carbon trioxide $\left(\mathrm{CO}_{3}\right)$, carbon dioxide $\left(\mathrm{CO}_{2}\right)$, etc. Suspended particulate matter (SPM) concentration in the city exceeds the National Ambient Air Quality Standards. During 2003-2005, the level of SPM has increased from 250 to $400 \mu \mathrm{g} / \mathrm{m}^{3}$ in the city (UUDP 2007). Due to recent multiplying population growth, urbanization, industrialization and several unplanned development projects in Dehradun city have resulted in large scale ecological degradation which in turn has greatly affected the urban climate on alarming scales. 


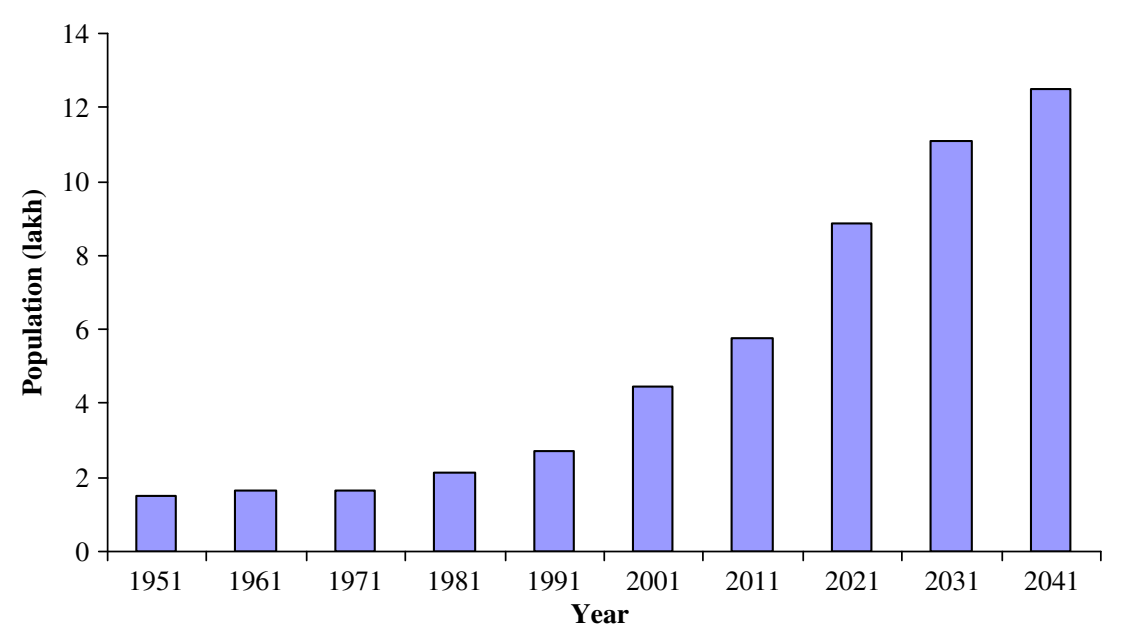

Figure 2. Evolution of the Dehradun city population according to national census of India.

Table 1. Development of built up area in Dehradun city during 1982-2004.

\begin{tabular}{lccc}
\hline & Built-up area (ha) & Built-up area (ha) & Growth in built-up area (\%) \\
Type of urban land use & 1982 & 2004 & $1982-2004$ \\
\hline Residential & 1588.8 & 4071.8 & 156.3 \\
Commercial & 81.0 & 341.4 & 321.5 \\
Industrial & 113.4 & 383.4 & 238.1 \\
Govt. and semi Govt. buildings & 267.2 & 479.6 & 79.5 \\
Facilities and services & 802.2 & 915.4 & 14.1 \\
Orchards and gardens & 205.7 & 728.4 & 254.1 \\
Open spaces and parks & 156.0 & 584.9 & 274.9 \\
Tourism and transportation & 203.0 & 822.0 & 304.9 \\
Rivers and nalas & 331.5 & 1179.3 & 255.7 \\
Undefined land use & 55.0 & 3058.8 & 5461.5 \\
Total & 3802.8 & 12565.0 & 230.4 \\
\hline
\end{tabular}

Source: UUDP (2007).

\section{Data and methods}

The daily temperature and vapour pressure data recorded by the meteorological observatory located at New Forest, Forest Research Institute, Dehradun in Doon valley of Uttarakhand for the period 1967-2007 were collected from the published records. All temperature and vapour pressure measurements were recorded at $0719 \mathrm{hrs}$ and 1419 hrs. The elevation of the meteorological observatory is about $640.08 \mathrm{~m}$ above mean sea level. This observatory corresponds to class 'A' meteorological observatory of India Meteorological Department (IMD), Pune. IMD is the only reliable, competent and official source in India for meteorological data.

From the daily time series temperature data (1967-2007) annual maximum, annual minimum and annual mean temperature were derived to find out the possible changes in temperature of the hilly city of Uttarakhand. To determine an yearly variation in temperature series and to identify the warmest and coldest phases, 5-year moving averages technique was adopted. The linear regression method was used to analyze the behaviour of annual maximum, annual minimum and annual mean temperature for 41 years (1967-2007). The data was analyzed in three ways: first, the whole study period 1967-2007, then dividing the whole period into two phases, i.e., 1967-1987 and 19882007. Trend line on each graph was used to get the clear picture of the results. Temperature is used as dependent variable while the time period is used as independent variable which is specified as: temperature $=t$ (time) and $Y=(\alpha+\beta X+\mu)$. Where $Y=$ mean temperature (minimum, maximum), $X=$ time period and $\mu=$ error/random term. The $t$-value of each parameter is calculated to check the statistical significance that null 
hypothesis Ho: $\beta=0$. The student's $t$ statistics is calculated as:

$$
t_{\mathrm{cal}}=\frac{\widehat{\beta}}{\mathrm{S} . \mathrm{E} \cdot(\widehat{\beta})}
$$

where $\beta$ is the coefficient (i.e., slope) and S.E. is the standard error of $\beta$ which shows the rate of change in temperature per unit time. It is calculated as:

$$
S_{y x}=\sqrt{\frac{\sum(y-\bar{y})^{2} \frac{\left[\sum(x-\bar{x})(y-\bar{y})\right]^{2}}{\sum(x-\bar{x})^{2}}}{n-2}}
$$

where $n$ is the sample size.

Furthermore, for better understanding of the observed trends in temperature, anomalies of annual maximum, annual minimum and annual mean temperature were also computed. Anomalies are more accurate than absolute temperature to describe climatic variability. To analyze anomalies in maximum, minimum and mean temperature, the average annual maximum, annual minimum and annual mean temperatures were calculated for the entire 1967-2007 period and subsequently, it was subtracted from yearly average maximum, minimum and mean temperature. Folland et al. (1999) suggested 30 years as a standard period for calculating the average used to analyze the anomalies. For the present purpose, the relative anomalies and comparison were made with the results obtained using the average from the whole dataset. The temperature anomalies obtained were plotted against time and the linear trends observed were represented graphically. The linear trend value, represented by the slope of a simple least-square regression line with time as the independent variable shows the magnitude of rise or fall in temperature.

Data of urban built up area, resident population, floating population and vehicles were also analyzed in tabular and graphical format to identify the problems of expansion of Dehradun city.

\section{Results and discussions}

\subsection{Trends and anomalies in annual maximum temperature}

The annual maximum temperature trends with 5 -year moving average have been presented in figure 3(a). The long term annual maximum temperature at Dehradun was found to be $28^{\circ} \mathrm{C}$ during the study period. The 5-year moving average in annual maximum temperature at Dehradun showed two periods of warming and two periods of cooling during 1967-2007. Remarkable cooling period was observed during 1972-1989 (figure 3a). The warmest year was 1967 with annual maximum temperature of $28.9^{\circ} \mathrm{C}$ which was $0.9^{\circ} \mathrm{C}$ warmer than the normal. The coolest year was 1997 with the annual maximum temperature $26.5^{\circ} \mathrm{C}$, when the drop was $1.5^{\circ} \mathrm{C}$ below the normal. The

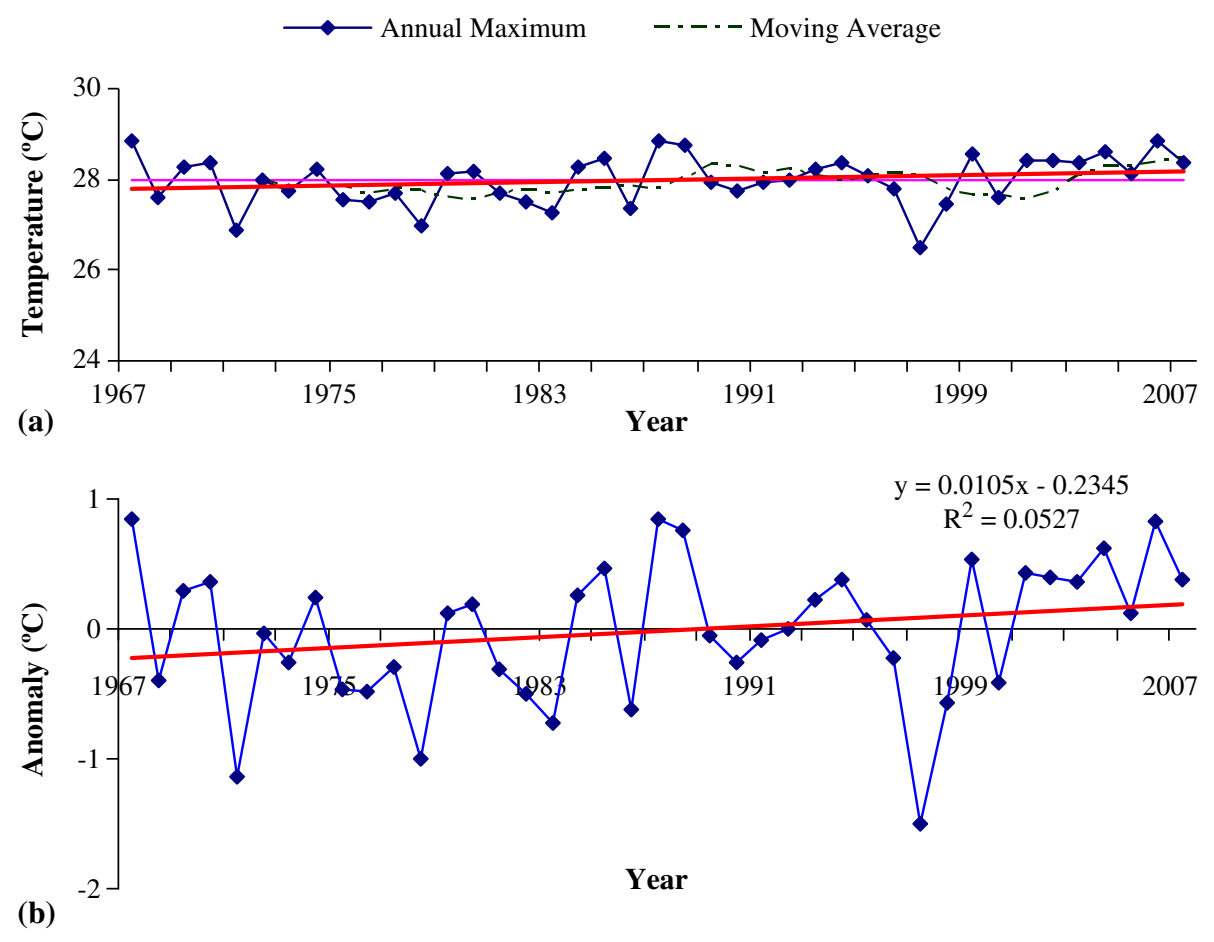

Figure 3. (a) Annual maximum temperature variations and (b) anomalies at Dehradun during 1967-2007. 
linear trend in annual maximum temperature from 1967-2007 at Dehradun indicated the increasing trend and the observed increase was found to be about $0.43^{\circ} \mathrm{C}$. The increasing annual maximum temperature results observed at Dehradun are in good agreement with the findings of other urban studies on the climate change in the Himalayas (Bhutiyani et al. 2007, 2010). This rise in annual maximum temperature has been attributed to increasing anthropogenic activities in the Himalayan region (Bhutiyani et al. 2007).

The anomalies of time series data for annual maximum temperature have been presented in figure $3(\mathrm{~b})$. Positive anomaly of about $0.85^{\circ} \mathrm{C}$ in annual maximum temperature was observed during 1967 whereas negative anomaly of about $1.5^{\circ} \mathrm{C}$ in annual maximum temperature was observed in the year 1997. It was also observed from the analysis that positive anomalies are more prominent in annual maximum temperature (figure $3 \mathrm{~b}$ ). Moreover, the analysis also demonstrated that change in annual maximum temperature is not uniform during the whole study period. Annual maximum temperature in first phase (1967-1987) increased $0.33^{\circ} \mathrm{C}$ while in later phase $(1988-2007)$, it maximized up to $0.42^{\circ} \mathrm{C}$. The anomalies of annual maximum temperature during two phases highlighted that there is almost no change in their occurrence but after the year 2000, the analysis revealed increasing trends in annual maximum temperature. The increasing intensity of anomalies in annual maximum temperature is higher than the annual minimum temperature which is greatly affecting the annual mean temperature during the study period (1967-2007). The value of $t$-statistics was also calculated to check the significance of annual maximum temperature. The regression coefficient of annual maximum temperature showed positive trends and it was found statistically significant at $5 \%$ level. However, the coefficient of the parameter was found to be negative during the first phase (1967-1987) while it was positive during the second phase (1968-2007). Moreover, these coefficients of annual maximum temperature were found to be non-significant during both the phases.

\subsection{Trends and anomalies in annual minimum temperature}

The annual minimum temperature trend with 5year moving averages has been presented in figure 4(a). The long term annual minimum temperature at Dehradun was observed to be $13.5^{\circ} \mathrm{C}$ during 1967-2007. The 5-year moving averages closely followed the trend line and intermittent periods of cooling and warming in annual minimum temperature were observed at Dehradun. However, remarkable warming period has been observed since 1998 (figure 4a). The annual minimum temperature ranged between $12.2^{\circ} \mathrm{C}$ in 1989 and $14.5^{\circ} \mathrm{C}$ in 1985. Therefore, the warmest year during the study period in terms of annual minimum temperature was 1985 when it was found $0.9^{\circ} \mathrm{C}$ warmer than the normal whereas the coolest year was 1989 when

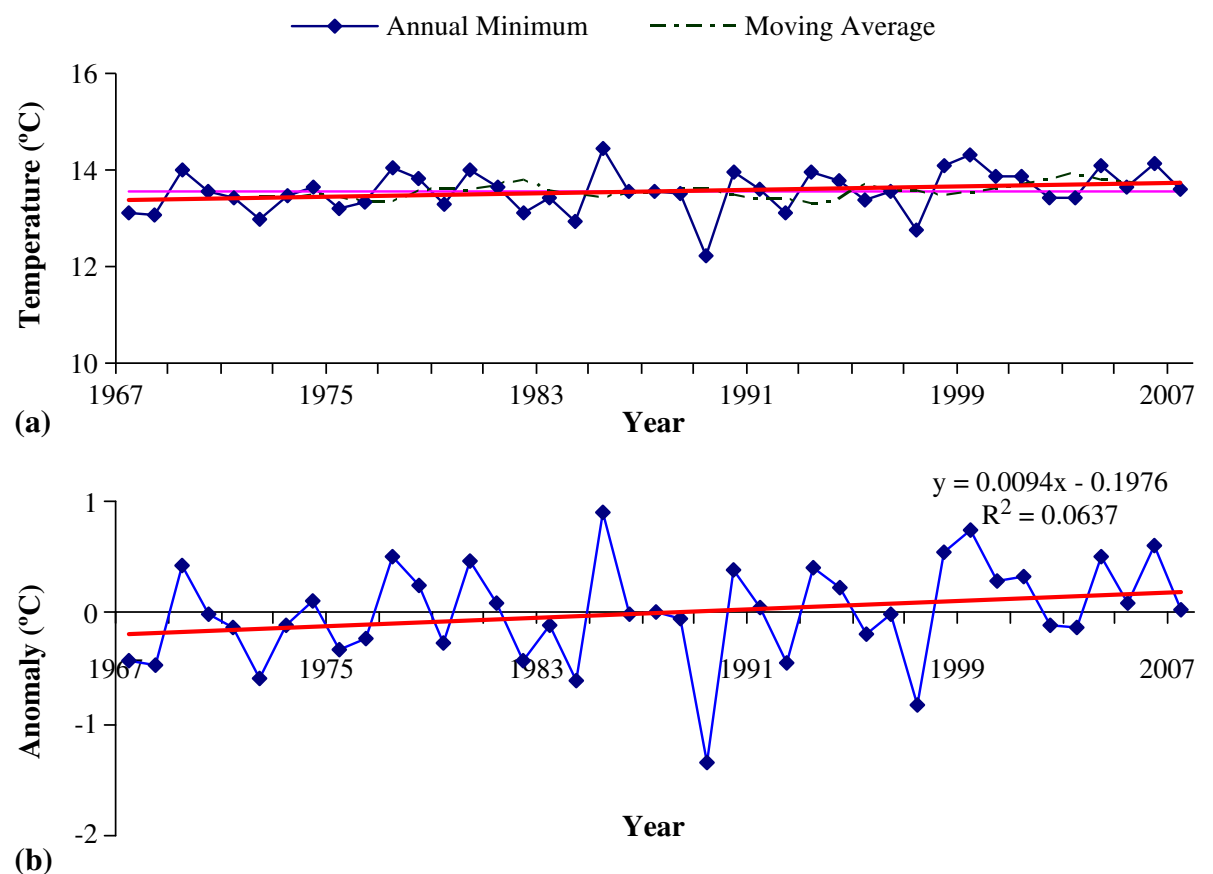

Figure 4. (a) Annual minimum temperature variations and (b) anomalies at Dehradun during 1967-2007. 
the drop was found to be $1.3^{\circ} \mathrm{C}$ below the normal. The linear trend in annual minimum temperature from 1967-2007 at Dehradun also indicated the increasing trend and the observed increase was found to be about $0.38^{\circ} \mathrm{C}$. The obtained results of annual minimum temperature are in conformity with the temperature trends at Ranichauri in the mid Himalayan region of Uttarakhand (Murty et al. 2004). The increasing trend in annual minimum temperature at Dehradun was noticed from the year 1983. The increase in magnitude of annual minimum temperature was observed to be $0.007^{\circ} \mathrm{C} /$ year and $0.98^{\circ} \mathrm{C} / 100$ year.

Positive anomaly of about $0.9^{\circ} \mathrm{C}$ in annual minimum temperature was observed during 1985. It was also observed from the analysis that negative anomalies are more prominent in annual minimum temperature at Dehradun (figure $4 \mathrm{~b}$ ). The observed data also make it clear that annual minimum temperature at Dehradun demonstrated an increase of $0.30^{\circ} \mathrm{C}$ during first phase whereas the increase almost doubled $\left(0.59^{\circ} \mathrm{C}\right)$ during the second phase. Other meteorological observations of annual minimum temperature in Himalayas and that out of the Himalayan region (Delhi, Kolkata and Chennai) also observed increasing annual minimum temperatures (Dhorde et al. 2009; Bhutiyani et al. 2007, 2010). The anomalies in annual minimum temperature during the second phase were more pronounced. However, noticeable increase in annual minimum was not noticed during the second phase. The regression of annual minimum temperature showed positive trends though it was not found to be significant. Moreover, coefficient of regression in annual minimum temperature were found to be positive and non-significant during the two phases.

\subsection{Trends and anomalies in annual mean temperature}

Observed annual mean temperature is affected both by maximum and minimum temperature. The long term annual mean temperature at Dehradun was observed to be $20.8^{\circ} \mathrm{C}$ during the study period. As revealed from figure 5(a) annual mean temperature witnessed a continuous period of warming since the year 2000 at Dehradun. Over the period under observation, 1999 was the warmest year with annual mean temperature $22.3^{\circ} \mathrm{C}$ when temperature rose $1.5^{\circ} \mathrm{C}$ more than the normal. The year 1997 on the other hand was the coolest year with annual mean temperature $19.6^{\circ} \mathrm{C}$ and the temperature was $1.2^{\circ} \mathrm{C}$ lower than the normal. Likewise, the linear trend in annual mean temperature at Dehradun also indicated the increasing trend and the observed increase were found to be about $0.47^{\circ} \mathrm{C}$ during the whole study period but this change in first phase was not found to be more pronounced than the phase two. During 1967-1987, annual mean temperature increased only $0.12^{\circ} \mathrm{C}$ which is only $25 \%$ of the total change. While during
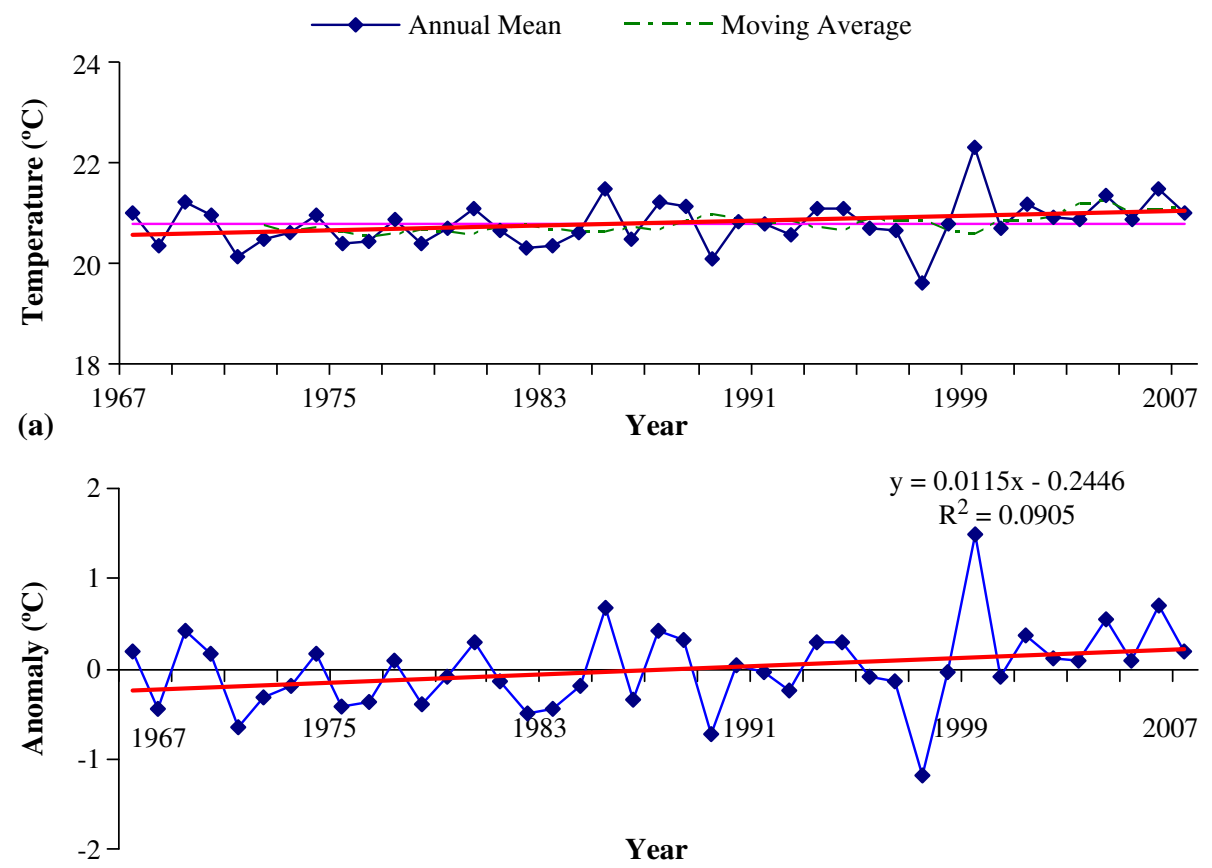

(b)

Figure 5. (a) Annual mean temperature variations and (b) anomalies at Dehradun during 1967-2007. 

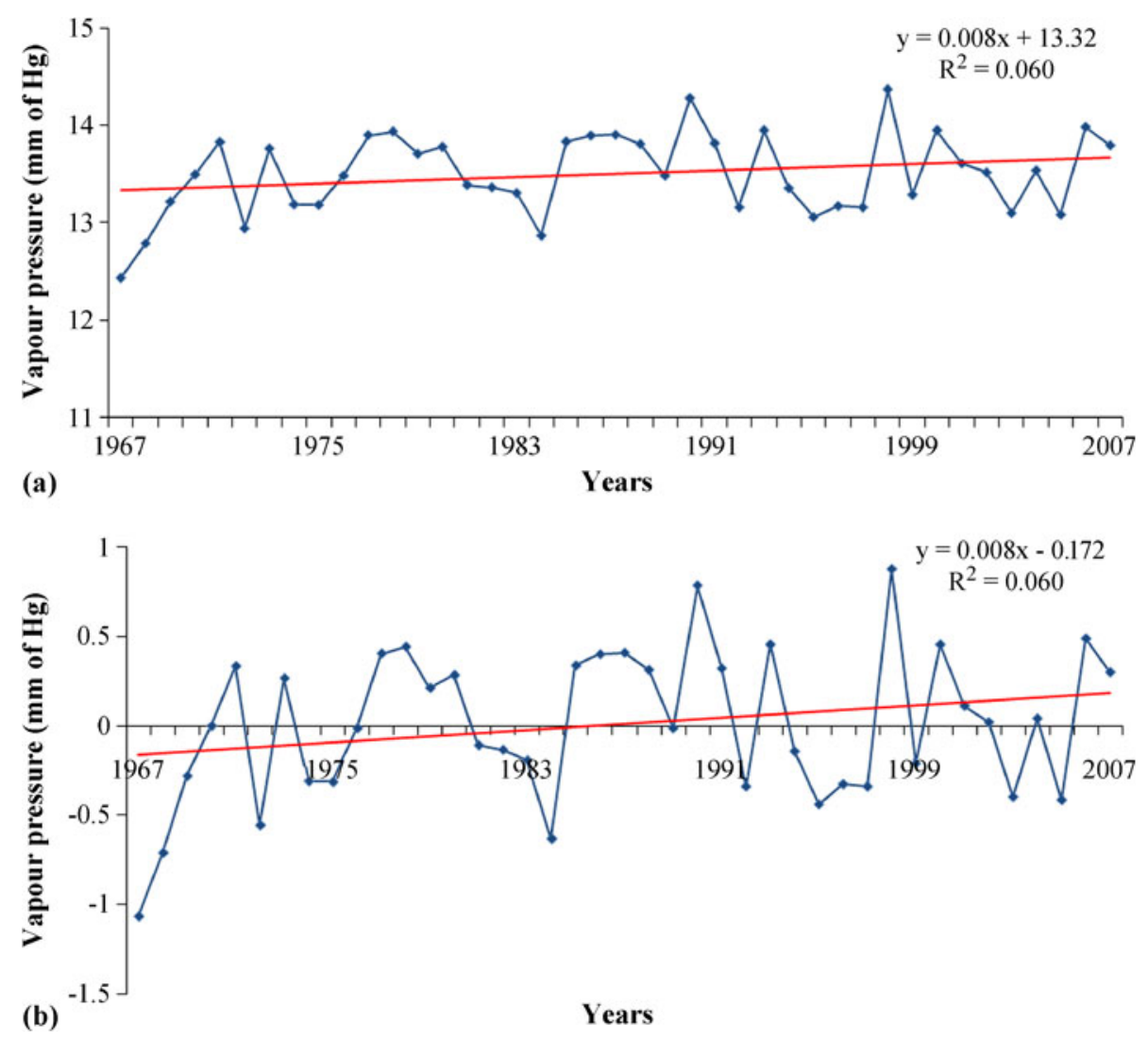

Figure 6. (a) Annual vapour pressure variations and (b) anomalies at Dehradun during 1967-2007.

1988-2007, it increased up to $0.54^{\circ} \mathrm{C}$ which is about $110 \%$ of the total change during the 41 -year period. Moreover, negative anomalies were found to be more pronounced during first phase whereas positive anomalies in annual mean temperature were more prominent during second phase (figure 5b). More positive anomalies in annual mean temperature during the phase can be attributed to urbanization process in Dehradun city. The regression of annual mean temperature demonstrated positive trends and it was found statistically significant at 5\% level. The regression coefficient for the two phases were observed to be positive and non-significant.

Observed temperature changes (maximum, minimum and mean) at Dehradun have been corroborated with ancillary vapour pressure data for the study period 1967-2007 and it also revealed an increasing trend in annual vapour pressure variations and anomalies (figure $6 \mathrm{a}-\mathrm{b}$ ). This finding duly supports the speculation that temperature change at Dehradun is due to recent urbanization and industrialization process. Moreover, this also supports the theory that as the temperature increases vapour pressure also increases. To sum up, temperature (maximum, minimum and mean) increase is a reality at Dehradun in Doon valley.

\section{Conclusions}

All over the world, urban areas are being affected by urban climate change. Increasing temperatures at Karachi, Seoul, Kolkata, Mumbai, Ranchi, Bangalore, Chennai and Delhi are the global examples of urban climate change. Dehradun is the rapidly growing city not only in Uttarakhand state but also in Himalayan region and northern India in respect of urbanization and industrialization particularly after becoming the capital of newly carved out state since the year 2000. About $114 \%$ growth in urban population since 1991 and $230 \%$ growth in urban built up area have been observed since 1982 in Dehradun city. Moreover, the declaration of new industrial development policy for the Uttarakhand state in the year 2003 led to the establishment of hundreds of medium and small scale industries on vast areas all around the city has caused mass scale rural-urban migration. Therefore, Dehradun city of Uttarakhand state in India is highly vulnerable to urban climate change mostly due to anthropogenic activities. The annual maximum, annual minimum and annual mean temperatures at Dehradun city have positive trends of change. Overall it has warmed significantly and annual mean temperature has increased about $0.47^{\circ} \mathrm{C}$ 
during the 41-year period (1967-2007). Per decade increase in annual mean temperature was found to be $0.12^{\circ} \mathrm{C}$ which is about four times more than the global increase of temperature. The time period during 1967-1987 has less intensity of temperature growth than the time period 1988-2007. The contribution of first phase in increasing the mean temperature was found to be only $25 \%\left(0.12^{\circ} \mathrm{C}\right)$ while the second phase has contributed about $110 \%$ $\left(0.54^{\circ} \mathrm{C}\right)$. This alarming rise in temperature can be attributed to the process of industrialization, urbanization, land use/land cover changes, construction activities, expansion of built-up areas, construction of roads and pavements, mining activities, etc., which were initiated in Dehradun city during second phase (1988-2007). Moreover, if the temperature of Dehradun city continue to increase at the same rate $\left(0.12^{\circ} \mathrm{C}\right)$, then it is possible that temperature will rise up to $1.2^{\circ} \mathrm{C}$ till the end of this century. This level of climatic warming at the Dehradun city will result into fatal effects on natural ecosystems. One of the obvious effects of temperature increase may lead to change in hydrological cycle and decrease in agricultural productivity in Doon valley. The results obtained from the study will also prove beneficial to the town planners who can make different strategies to mitigate the urban effects on rising temperature in India and especially in Uttarakhand and Himalayan region.

\section{Acknowledgement}

The authors gratefully acknowledge the Forest Research Institute, Dehradun for providing the published data used in this study.

\section{References}

Alam M and Golam Rabbani M D 2007 Vulnerabilities and responses to climate change for Dhaka; Environ. Urban. 19 81-97.

Arora A, Goel A K and Singh P 2005 Evaluation of temperature trends over India; Hydrol. Sci. J. 50 81-93.

Bhutiyani M R, Kale V S and Pawar N J 2007 Longterm trends in maximum, minimum and mean annual air temperatures across the Northwestern Himalaya during twentieth century; Climatic Change 85 159-177.

Bhutiyani M R, Kale V S and Pawar N J 2010 Climate change and the precipitation variations in the northwestern Himalaya: 1866-2006; Int. J. Climatol. 30 535-548.

Bounoua L, Defries R S, Imhoff M L and Steininger M K 2004 Land use and local climate: A case study near Santa Cruz, Bolivia; Meteorol. Atmos. Phys. 86 73-85.

Catherine S and Sue G 2006 Applied climatology: Urban climate; Progr. Phys. Geogr. 30 270-279.

Chung Y S, Yoon M B and Kim H S 2004a On climate variations and changes observed in South Korea; Climatic Change 66 151-161.

Chung U, Choi J and Yun J I 2004b Urbanization effect on the observed change in mean monthly temperature between 1951-1980 and 1971-2000 in Korea; Climatic Change 66 127-136.

Dash S K and Hunt J C R 2007 Variability of climate change; Curr. Sci. 96 782-788.

De U S and Dandekar M M 2001 Natural disasters in urban areas; Deccan Geographer 39 1-12.

De U S and Prakasa Rao G S 2004 Urban climate trends the Indian scenario; J. Indian Geophys. 8 199-203.

Dhorde A, Dhorde A and Gadgil A S 2009 Long term temperature trends at four largest cities of India during the twentieth century; J. Indian Geophys. Union 13 85-97.

Edmilson F D, Rozoff Christopher M, Cotton William R and Silva Dias Pedro L 2007 Interactions of an urban heat island and sea breeze circulation during winter over the metropolitan area of Sao Paulo, Brazil; Bound.-Layer Meteorol. 122 43-65.

Folland C K, Miller C, Bader D, Crowe M, Jones P, Plummer P, Richman M, Parker D E, Rogers J and Sholefield P 1999 Temperature indices for climate extremes; Climatic Change 42 31-43.

Fujibe F 1995 Temperature rising trends at Japanese cities during the last hundred years and their relationships with population, population increasing rates and daily temperature ranges; Meteorol. Geophys. 46 $35-55$.

Fujibe F 2009 Detection of urban warming in recent temperature trends in Japan; Int. J. Climatol. 29 1811-1822.

Gadgil A and Dhorde A 2005 Temperature trends in twentieth century at Pune, India; Atmos. Environ. 39 6550-6556.

Goodridge J D 1992 Urban bias influences on long term California air temperature trends; Atmos. Environ. 26B $1-7$.

Gupta A 2004 Geoindicators for tropical urbanization; Environ. Geol. 42 736-742.

Hung T, Uchihama D, Ochi S and Yasuoka Y 2006 Assessment with satellite data of the urban heat island effects in Asian mega cities; Int. J. Appl. Earth Observation and Geoinform. 8 34-48.

Intergovernmental Panel on Climate Change 2007 Climate change 2007: The physical science basis; In: Contribution of Working Group I to the Fourth Assessment Report of the Intergovernmental Panel on Climate Change (eds) Soloman S, Qin D, Manning M, Chen Z, Marquis M, Averyt K B, Tignor M and Miller H L, Cambridge University Press, Cambridge.

Kadioğlu M 1997 Trends in surface air temperature data over Turkey; Int. J. Climatol. 17 511-520.

Kumar V P, Bindi M, Crisci A and Maracchi G 2005 Detection of variation in air temperature at different time scale during the period 1889-1998 at Firenze, Italy; Climatic Change 72 123-150.

Liu W, Ji C, Zhong J, Jiang X and Zheng Z 2007 Temporal characteristics of the Beijing urban heat island; Theor. Appl. Climatol. 87 213-221.

Murty N S, Gaira K S and Singh R K 2004 Temperature variations at Ranichauri in the Mid Himalayan region of Uttaranchal; J. Agrometeorol. 6 227-232.

Ohashi Y, Kondo H, Genchi Y, Kikegawa Y, Yoshikado H and Hirano Y 2007 Influence of air-conditioning waste heat on air temperature in Tokyo during summer: Numerical experiments using an urban canopy model coupled with a building energy model; J. Appl. Meteorol. Climatol. 46 66-81.

Oleson K W, Bonan G B, Feddema J, Veretenstein M and Grimmond C S B 2008 An urban parameterization for a global climate model. Part I: Formulation and 
evaluation for two cities; J. Appl. Meteorol. Climatol. 47 1038-1076.

Rana A, Uvo C B, Bengtsson L and Sarthi P P 2012 Trends analysis for rainfall in Delhi and Mumbai, India; Clim. Dynam. 38 45-56.

Revadekar J V, Kothawale D R, Patwardhan S K, Pant G B and Rupa Kumar K 2012 About the observed and future changes in temperature extremes over India; Nat. Hazards $601133-1155$

Roth M 2007 Review of urban climate research in subtropical regions; Int. J. Climatol. 27 1859-1873.

Sajjad S H, Hussain B, Khan M A, Raza A, Zaman B and Ahmed I 2009 On rising temperature trends of Karachi in Pakistan; Climatic Change 96 539-547.

Singh P, Kumar V, Thomas T and Arora M 2008 Basinwide assessment of temperature trends in north-west and central India; Hydrol. Sci. J. 53 421-433.

Tayanc M and Toros H 1997 Urbanisation effects on regional climate change in the case of four larger cities of Turkey; Climatic Change 35 501-524.

Thapliyal V and Kulshreshtha S M 1991 Climate changes and trends over India; Mausam 42 333-338.
Tigga A and Hema Malini B 2011 Temperature trends in Ranchi city, Jharkhand; Punjab Geogr. 7 20-31.

Trusilova K, Jung M, Churkina G, Karstenes U, Heimann M and Claussen M 2008 Urbanization impacts on the climate in Europe: Numerical experiment by the PSUNCAR Mesoscale Model (MM5); J. Appl. Meteorol. Climatol. 47 1442-1455.

UNFPA 2009 State of world population 2009 Facing a changing world: Women, population and climate; United Nations Population Fund, New York, p. 104.

Uttaranchal Urban Development Project 2007 Urban Development Department, Government of Uttaranchal, Dehradun, p. 65.

Xu Y, Qin Z and Wan H 2010 Spatial and temporal dynamics of urban heat island and their relationship with land cover changes in urbanization process: A case study in Suzhou, China; J. Indian Soc. Rem. Sens. 38 654-663.

Yilmaz S, Toy S, Yildiz N D and Yilmaz H 2009 Human population growth and temperature increase along with the increase in urbanization, motor vehicle numbers and green area amount in the sample of Erzurum city, Turkey; Environ. Monitoring Assess. 148 205-213. 